\title{
Engaging stakeholders to assess landscape sustainability
}

\author{
Virginia H. Dale (i) - Keith L. Kline (iD) - Esther S. Parish (D) Sarah E. Eichler (i)
}

Received: 3 June 2019/Accepted: 10 June 2019/Published online: 24 June 2019

(C) The Author(s) 2019

\begin{abstract}
Context There is widespread consensus about the need for landscape sustainability but little agreement about how to define or measure it.

Objectives The aim of the paper is to present a systematic approach for measuring progress toward landscape sustainability goals.

Methods The approach was developed based on existing literature and our experiences in applying the approach to support more sustainable agricultural landscapes. Examples applying this approach are summarized for case studies in the United States (U.S.) and Mexico.
\end{abstract}

V. H. Dale $(\bowtie)$

Department of Ecology and Evolutionary Biology, University of Tennessee, Knoxville, TN, USA

e-mail: vdale@utk.edu

V. H. Dale

Oak Ridge National Laboratory, Oak Ridge, TN, USA

K. L. Kline · E. S. Parish

Environmental Sciences Division, Oak Ridge National

Laboratory, Oak Ridge, TN, USA

e-mail: klinekl@ornl.gov

E. S. Parish

e-mail: parishes@ornl.gov

\section{S. E. Eichler}

Department of Plant Science, Pennsylvania State

University, University Park, PA, USA

e-mail: sarah.e.eichler@gmail.com
Results The approach has six steps: the scope and objectives of the assessment are determined based on the particular context; indicators that alert pending concerns are selected and prioritized based on utility and relevance; baselines and targets are established for each indicator, and scenarios for consideration are determined; the indicator values are obtained and evaluated; trends in and tradeoffs among indicator values are analyzed; and good practices are developed, applied, and assessed.

Conclusions Insights gained from applying this approach suggest that designing sustainable landscapes depends on stakeholder engagement, effective communication, transparency and trust, timely monitoring, and continual improvement. Iterative application of the assessment approach builds capacity and promotes continual improvements in management practices, thus enabling timely responses to changing conditions while still progressing toward a set of locally defined goals.

Keywords Agriculture - Bioenergy - Landscape sustainability $\cdot$ Indicators $\cdot$ Stakeholders $\cdot$ Tradeoffs

\section{Introduction}

Building from relationships between pattern and process, landscape sustainability science is a place- 
based means to understand and improve the dynamic interactions between ecosystem services and human well-being under changing conditions and uncertainties (Pearson and McAlpine 2010; Musacchio 2013; Wu 2013). Focusing on the sustainability of a landscape requires assessing how processes interact over time so as not to compromise the benefits they provide. Whereas there is strong consensus regarding the need for sustainability, there is little agreement about what method or metrics should be used to measure it. A literature review of sustainability indicators for agriculture identified 294 unique metrics (Rasmussen et al. 2017). Hundreds of additional metrics have been proposed to measure sustainability associated with specific processes and commodities (e.g., Ashok et al. 2017; Genovese et al. 2017; Carlsson et al. 2017; Smith et al. 2017; Wheaton and Kulshreshtha 2017) and applied to more than 460 different products (EcoLabel Index 2018; Yokessa and Marette 2019). While Vörösmarty et al. (2018) caution that businesses are criticized for "green washing" their sustainability ratings unless a standard method is adopted, attempts to standardize approaches for measuring landscape sustainability have been frustrated by the diversity of contexts and issues and sometimes result in laundry lists of guidelines rather than specific methods that enable consistent measurement and unambiguous results. Identifying effective practices to meet long-term objectives is a key challenge in developing an approach that guides practical decisions about landscapes (Williams and Brown 2012; Opdam et al. 2018). Changing environmental, social, and economic conditions make this effort especially difficult. Addressing this challenge requires multiple disciplines and systems integration (Jordan and Davis 2015)—including simultaneous incorporation of human and natural components, quantification of underlying effects and feedbacks, and consideration of multiple spatial and temporal scales (Miller et al. 2014; Liu et al. 2015).

Our goal in this paper is to provide a structured approach that is useful in quantifying progress toward landscape sustainability and helping users advance toward shared goals. This approach is an evaluation that identifies essential features of the landscape and what needs to be done to maintain its distinctive qualities. The assessment approach is meant to be adaptable to diverse situations, each with unique constraints, opportunities, and stakeholders with distinct values and priorities (Johnson et al. 2003; Ness et al. 2007; Sydorovych and Wossink 2008; Cebrián-Piquerasa et al. 2017). The proposed approach synthesizes insights from literature and our own experiences with resource management in landscapes where agricultural production is a dominant factor. This approach evolved through decades of trial and error in programs designed to measure and achieve specific goals. We provide examples that underscore the difficulties that practitioners encounter when they attempt to assess landscape sustainability. Our ultimate objective in sharing this approach is to support a community of practice that shapes "living" landscapes to maximize potential benefits while minimizing negative impacts (Palmer 2012; Dale et al. 2015; Muneepeerakul and CastilloChavez 2015; Vörösmarty et al. 2018; Opdam et al. 2018).

\section{A six-step process for assessing progress toward landscape sustainability}

The landscape sustainability assessment process is triggered by a need to evaluate a production system, product, technology, investment, policy, or other discreet intervention (herein called the activity) designed to meet specified societal needs or maintain environmental benefits. Indeed, determining for whom or for what sustainability is intended is a key question that must be addressed for the concept to be implemented (Wiens 2013). An interested party, herein called the coordinator, initiates the assessment and engages relevant stakeholders in the landscape sustainability assessment process within specified context and goals (e.g., Cebrián-Piquerasa 


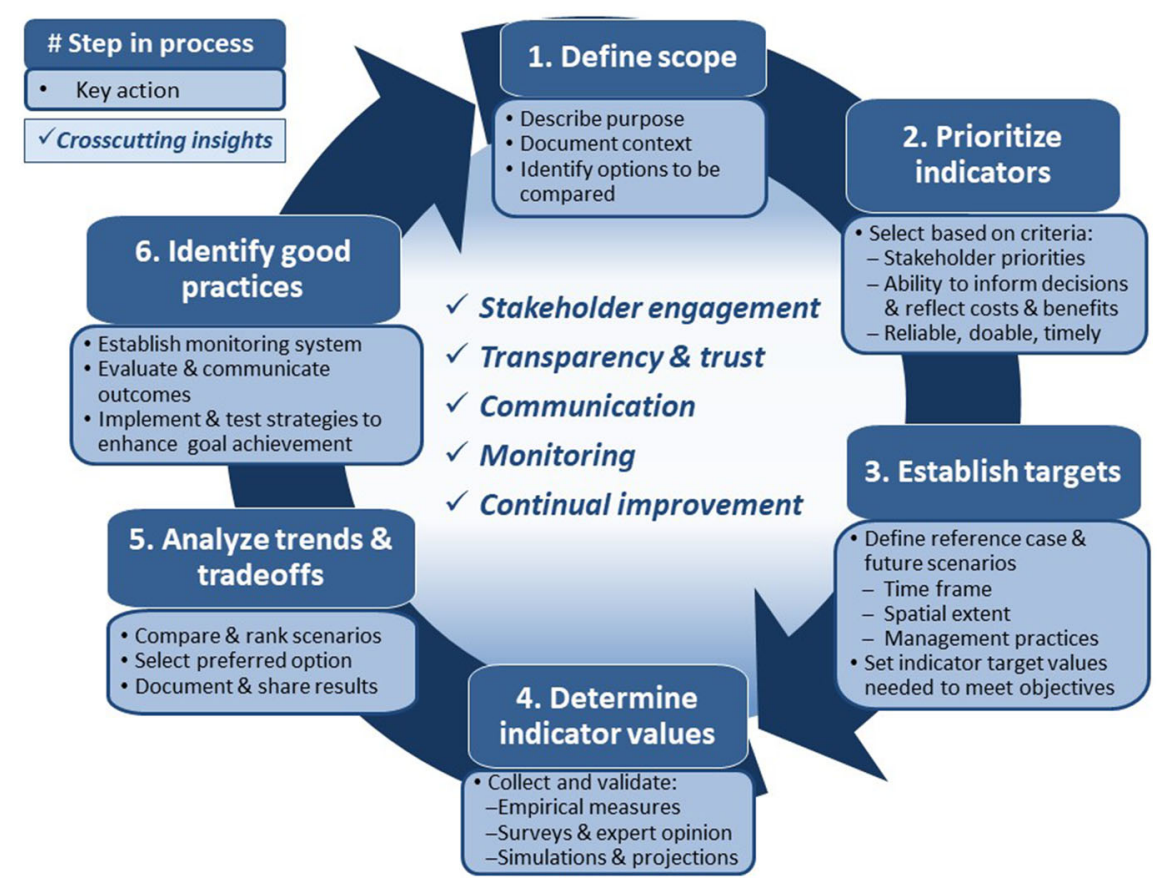

Fig. 1 Six steps and cross-cutting insights for assessing progress toward sustainability goals

et al. 2017; Efroymson et al. 2013; Petersen et al. 2018). The coordinator may be a government official, scientist, or a representative from industry, local community, or a non-governmental organization (NGO). The coordinator organizes and oversees the assessment process and, to be successful, should be trusted by stakeholders (Beardsley 2011) or, at minimum, be considered an "honest broker" (Varner 2014). The coordinator drafts the sustainability assessment objectives and context, which establish the spatial and temporal boundaries of the process and identify major stakeholders. These objectives and context may be modified during the assessment process, for learning about the system occurs as the "living" evaluation is deployed.
Each of the six steps of the landscape sustainability assessment approach requires actions and decisions illustrated by the decision-making cycle shown in Fig. 1 and detailed in the following subsections. While several steps can be initiated simultaneously, finalization of later steps depends on completion of the prior steps. Iterations within and among the steps are common, as each step is influenced by new information. And the entire circuit may be reinitiated as goals are adjusted in light of changing conditions, priorities, and available information toward agile decision making. The decision-making cycle is underlain by five essential themes discussed in a final section of this manuscript: stakeholder engagement, timely and effective communication, transparency and trust, monitoring, and continual improvement (Box 1). 
Box 1: Terminology used to define and assess landscape sustainability

Landscape sustainability is the capacity of a landscape to consistently provide long-term, landscape-specific ecosystem services that are essential for maintaining and improving human well-being (Wu 2013).

Stakeholders are all persons and groups that influence the activity or may be affected positively or negatively by changes in the provision of ecosystem services or socioeconomic conditions associated with the activity.

Indicators are measurements that can be used to monitor trends in conditions over time or to provide early warning of change (Cairns et al. 1993).

Continual improvement is a systematic and iterative process to identify, evaluate, and select options that provide incremental progress toward achieving defined goals and objectives (ASTM 3066a 2017).

Adaptive management is an approach to guide decisions based on learning from trial and error that involves exploring alternative hypotheses of actions to meet a management objective by predicting outcomes of alternative management actions, implementing some of the alternatives, monitoring to learn about effects of particular management actions, and then using those results to adjust management actions (Williams and Brown 2012). In practice, adaptive management is applied in many different ways to support the process of continual improvement in a specific context.

\section{Define scope}

Defining the objectives for an assessment requires clarity about the plans and goals for the activity, the landscape assessment process and stakeholders and their aims. The temporal and spatial extent (i.e., system boundaries for the assessment) are largely determined by the location and the extent of costs and benefits coming from the activity. Identifying boundaries can be difficult in practice, particularly if the area supports a production system (such as agriculture) and products or wastes are exported beyond the area of production (e.g., see Galik and Abt 2016). A telecoupling framework has been proposed by Liu et al.
(2013) for considering causal connections or correlations between environmental phenomena that occur across large distances. Understanding past trends, current conditions, and potential future conditions for the system is essential, as is identifying expected decisions that will be most relevant to the assessment (Efroymson et al. 2013; Petersen et al. 2018).

The context of the assessment process strongly affects the choice, measurement, and interpretation of indicators and other measurements that provide information about potential or realized effects of human activities on environmental, social, or economic phenomena of concern (Heink and Kowarik 2010; Efroymson et al. 2013). Other context considerations include the specific purpose of the assessment, the distribution system(s) associated with any production systems in the landscape, policy influences, stakeholders' values, baseline attributes, information availability, spatial and temporal scales of interest, material and energy flows through the system, and the ecosystem services that might be affected (Efroymson et al. 2013; Dale et al. 2018a; Eichler Inwood et al. 2018). The land area of focus may be the region that supports the cultivation and refining of specific products or the area expected to be affected by a proposed new production system or intervention. Given water's essential role in supporting life on earth, watersheds are useful units of landscape analysis because effluent characteristics at the outlet reflect the integrated effects of management decisions made throughout the contributing land area (e.g., Ice 2011; Williams and Brown 2012). Throughout this initial step of defining the scope, there is a need to engage stakeholders in ways that help them understand how activities within a local landscape interact with and form part of global phenomena that affect and are affected by that landscape (Opdam et al. 2018).

\section{Prioritize indicators}

Appropriate indicators are needed to assess environmental, social, and economic aspects of the activity. Determining indicators of impending critical transitions between states is one of the major challenges in the science of sustainability (Levin 2013). Indicators can be selected to achieve multiple goals such as (1) providing useful information that addresses priorities of stakeholders and decision makers, (2) capturing relevant costs and benefits across the entire landscape, 
Fig. 2 Framework for selecting sustainability indicators. Components of the indicator selection process are shown in dark orange. Light-colored shapes are aspects of the assessment process that use the indicators or support their selection. Adapted from Dale et al. (2015)

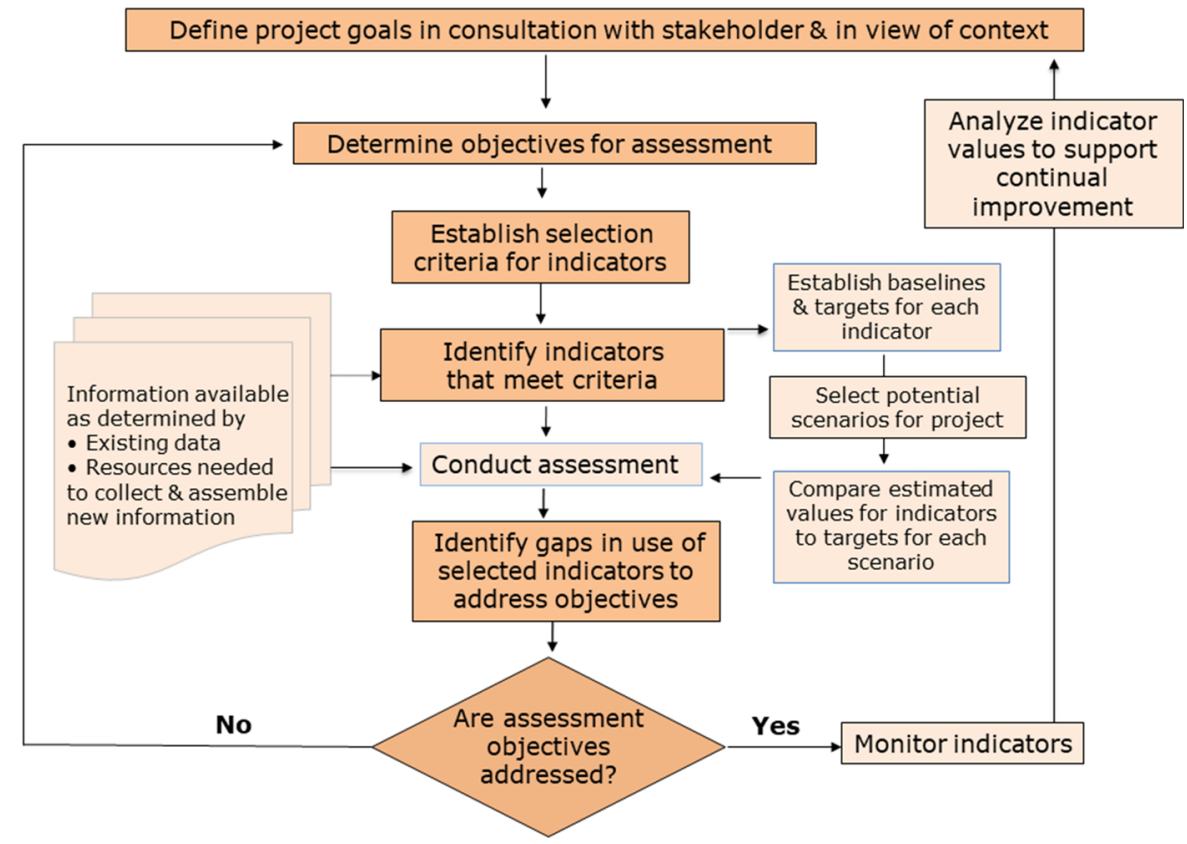

(3) facilitating measurement, or (4) supporting corrective actions (Cairns et al. 1993; Dale et al. 2015; Iacovidou et al. 2017).

A challenge faced when selecting indicators is to balance the desire to be comprehensive and the need to keep the process doable within limited constraints of time and budget while addressing inputs from diverse interests. The selected indicators should avoid redundancy and represent a minimum set of metrics required to address key concerns of stakeholders (e.g., Rasmussen et al. 2017). By selecting a few indicators that are sufficient to meet specific goals, the assessment process can avoid time and costs that would be incurred by adopting a longer list of indicators. However, oversimplification by having too few metrics can omit significant effects or situations that make it difficult to interpret and validate the information obtained (Landres et al. 1988).

Selecting indicators using an established framework (Fig. 2) (1) contributes to clarifying and building consensus around stakeholders' goals for a desired future outcome, (2) ensures that important stakeholder concerns are considered in the indicator-selection process, (3) identifies a suite of indicators that is appropriate for the context of the analysis, (4) yields a high amount of information relative to the cost of obtaining relevant data, and (5) leads to higher likelihood of being applied and monitored over time (Dale et al. 2015; Garrick et al. 2017). Measurement is facilitated by selecting indicators that are practical, reliable, and provide timely information (Dale and Beyeler 2001).

To facilitate the process of selecting indicators, a checklist of categories of indicators was developed to reflect potential environmental (McBride et al. 2011), socioeconomic (Dale et al. 2013), and management (Eichler Inwood 2018) implications for landscapes (Table 1). However, some assessments may demand unique indicators that are not considered in generic lists and standards (Efroymson et al. 2013). For example, where land tenure and equity are key priorities for sustainability assessment (e.g., Bailis and Baka 2011; Anseeuw et al. 2012), corresponding indicators should be considered (FAO 2014).

\section{Establish targets}

A target is a future state indicating progress toward specific goals. Targets for each indicator should be clearly specified with input from stakeholders to describe a desired future condition (Dale et al. 2016; Hunter et al. 2017), and it is important for targets to represent the interests of future generations as well as near-term stakeholder goals (Dale et al. 2013). The 
Table 1 Checklist of environmental, social and economic, and management indicators for resource management in sustainable landscapes building from McBride et al. (2011), Dale et al. (2013), and Eichler Inwood (2018). Ideally the suite of indicators should represent key information about structure, function, and composition, but knowledge about any one of these features may provide information about other aspects of the system (Dale and Beyeler 2001). It is often easier to measure structural features that convey information about the composition or functioning of the system (Lindenmayer et al. 2000); so here we focus on indicators pertaining to structure

\begin{tabular}{|c|c|c|c|}
\hline Type & Category & Indicator & Units \\
\hline \multirow[t]{19}{*}{ Environmental } & \multirow[t]{4}{*}{ Soil quality } & 1. Total organic carbon (TOC) & $\mathrm{Mg} \mathrm{km}^{-2}$ \\
\hline & & 2. Total nitrogen $(\mathrm{N})$ & $\mathrm{Mg} \mathrm{km}^{-2}$ \\
\hline & & 3. Extractable phosphorus (P) & $\mathrm{Mg} \mathrm{km}^{-2}$ \\
\hline & & 4. Bulk density & $\mathrm{g} \mathrm{cm}^{-3}$ \\
\hline & \multirow[t]{7}{*}{$\begin{array}{l}\text { Water quality and } \\
\text { quantity }\end{array}$} & $\begin{array}{l}\text { 5. Nitrate concentration in streams (and } \\
\text { export) }\end{array}$ & $\begin{array}{l}\text { Concentration: } \mathrm{mg} \mathrm{L}^{-1} \text {; export: } \\
\mathrm{kg} \mathrm{km}^{-2} \text { year }^{-1}\end{array}$ \\
\hline & & $\begin{array}{l}\text { 6. Total phosphorus }(\mathrm{P}) \text { concentration in } \\
\text { streams (and export) }\end{array}$ & $\begin{array}{l}\text { Concentration: } \mathrm{mg} \mathrm{L}^{-1} \text {; export: } \\
\mathrm{kg} \mathrm{km}^{-2} \text { year }^{-1}\end{array}$ \\
\hline & & $\begin{array}{l}\text { 7. Suspended sediment concentration in } \\
\text { streams (and export) }\end{array}$ & $\begin{array}{l}\text { Concentration: } \mathrm{mg} \mathrm{L}^{-1} \text {; export: } \\
\mathrm{kg} \mathrm{km}^{-2} \text { year }^{-1}\end{array}$ \\
\hline & & $\begin{array}{l}\text { 8. Herbicide concentration in streams (and } \\
\text { export) }\end{array}$ & $\begin{array}{l}\text { Concentration: } \mathrm{mg} \mathrm{L}^{-1} \text {; export: } \\
\mathrm{kg} \mathrm{km}^{-2} \text { year }^{-1}\end{array}$ \\
\hline & & 9. Peak storm flow & $\mathrm{L} \mathrm{s}^{-1}$ \\
\hline & & 10. Minimum base flow & $\mathrm{L} \mathrm{s}^{-1}$ \\
\hline & & $\begin{array}{l}\text { 11. Consumptive water use (incorporates } \\
\text { base flow) }\end{array}$ & $\begin{array}{l}\text { Feedstock production: } \mathrm{m}^{3} \mathrm{~km}^{-2} \text { day }^{-1} \text {; } \\
\text { biorefinery: } \mathrm{m}^{3} \text { day }^{-1}\end{array}$ \\
\hline & GHG emissions & $\begin{array}{l}\text { 12. } \mathrm{CO}_{2} \text { equivalent emissions }\left(\mathrm{CO}_{2} \text { and }\right. \\
\left.\mathrm{N}_{2} \mathrm{O}\right)\end{array}$ & $\mathrm{kg} \mathrm{GJ}^{-1}$ \\
\hline & \multirow[t]{4}{*}{ Air quality } & 13. Tropospheric ozone & $\mathrm{ppb}$ \\
\hline & & 14. Carbon monoxide & ppm \\
\hline & & $\begin{array}{l}\text { 15. Total particulate matter less than } 2.5 \mu \mathrm{m} \\
\text { diameter }\left(\mathrm{PM}_{2 \cdot 5}\right)\end{array}$ & $\mu \mathrm{g} / \mathrm{m}^{3}$ \\
\hline & & $\begin{array}{l}\text { 16. Total particulate matter less than } 10 \mu \mathrm{m} \\
\text { diameter }\left(\mathrm{PM}_{10}\right)\end{array}$ & $\mu \mathrm{g} / \mathrm{m}^{3}$ \\
\hline & \multirow[t]{2}{*}{ Biodiversity } & 17. Presence of taxa of special concern & Presence \\
\hline & & 18. Habitat area of taxa of special concern & $\mathrm{km}^{2}$ \\
\hline & Productivity & $\begin{array}{l}\text { 19. Aboveground net primary productivity } \\
\text { (ANPP), yield }\end{array}$ & $\mathrm{g} \mathrm{m}^{-2}$ year $^{-1}$ \\
\hline \multirow{10}{*}{$\begin{array}{l}\text { Social and } \\
\text { economic }\end{array}$} & \multirow[t]{4}{*}{ Social wellbeing } & 1. Employment & Number of full time equivalent (FTE) jobs \\
\hline & & 2. Household income & Dollars per day \\
\hline & & 3. Work days lost due to injury & $\begin{array}{l}\text { Average number of work days lost per worker } \\
\text { per year }\end{array}$ \\
\hline & & 4. Food security & Percent change in food price volatility \\
\hline & \multirow[t]{2}{*}{ Energy security } & 5. Energy security premium & Dollars per liter of biofuel \\
\hline & & 6. Fuel price volatility & $\begin{array}{l}\text { Standard deviation of monthly percent price } \\
\text { changes over } 1 \text { year }\end{array}$ \\
\hline & \multirow[t]{2}{*}{ External trade } & 7. Terms of trade & Ratio (price of exports per price of imports) \\
\hline & & 8.Trade volume & Dollars (net exports or balance of payments) \\
\hline & \multirow[t]{2}{*}{ Profitability } & 9. Return on investment (ROI) & $\begin{array}{l}\text { Percent (net investment per initial } \\
\text { investment) }\end{array}$ \\
\hline & & 10. Net present value (NPV) & $\begin{array}{l}\text { Dollars (present value of benefits minus } \\
\text { present value of costs) }\end{array}$ \\
\hline
\end{tabular}


Table 1 continued

\begin{tabular}{|c|c|c|c|}
\hline Type & Category & Indicator & Units \\
\hline & $\begin{array}{l}\text { Resource } \\
\text { conservation }\end{array}$ & $\begin{array}{l}\text { 11. Depletion of non-renewable } \\
\text { energy resources }\end{array}$ & Amount of petroleum extracted per year $(t)$ \\
\hline & & $\begin{array}{l}\text { 12. Fossil Energy Return on } \\
\text { Investment (fossil EROI) }\end{array}$ & $\begin{array}{l}\text { Ratio of amount of fossil energy inputs to amount of useful } \\
\text { energy output (MJ) (adjusted for energy quality) }\end{array}$ \\
\hline & Social & 13. Public opinion & Percent favorable opinion \\
\hline & & 14. Transparency & $\begin{array}{l}\text { Percent of indicators for which timely and relevant performance } \\
\text { data are reported }\end{array}$ \\
\hline & & $\begin{array}{l}\text { 15. Effective stakeholder } \\
\text { participation }\end{array}$ & $\begin{array}{l}\text { Percent of documented responses addressing stakeholder } \\
\text { concerns and suggestions, reported on an annual basis }\end{array}$ \\
\hline & & 16. Risk of catastrophe & Annual probability of catastrophic event \\
\hline \multirow[t]{4}{*}{ Management } & $\begin{array}{l}\text { Soil } \\
\text { management }\end{array}$ & $\begin{array}{l}\text { 1. Area managed using soil tests } \\
\text { that support agriculture } \\
\text { decisions }\end{array}$ & Number of ha, number of farmers per area \\
\hline & & 2. Pesticide use & $\begin{array}{l}\text { Liters (or dollars spent) per hectare per year or per } \mathrm{kg} \text { of } \\
\text { production }\end{array}$ \\
\hline & $\begin{array}{l}\text { Water } \\
\text { management }\end{array}$ & 3. Irrigation water demand & $\begin{array}{l}\text { Cubic meters of water per ha and per } \mathrm{kg} \text { (or per } \$ \text { value) of } \\
\text { production }\end{array}$ \\
\hline & Crop rotation & $\begin{array}{l}\text { 4. Crop diversification to reduce } \\
\text { risk from extreme events }\end{array}$ & $\begin{array}{l}\text { Percent of area planted in the dominant crops; percent of crop } \\
\text { area planted to resilient varieties (to be determined by } \\
\text { discussions with local stakeholders) }\end{array}$ \\
\hline
\end{tabular}

time horizon for targets should consider when information is required to guide decisions so that timely corrective measures can be adopted if targets are not being met. Target values for indicators are established based on existing goals, local or regional planning, sustainable development goals, values in the literature, expert opinion, scientific analysis of the activity or similar systems, regulations such as threshold values for water or air quality, or the results of consensusbuilding among informed stakeholders (Moldan et al. 2012) (e.g., see examples described by Tarter et al. 2016).

Two or more scenarios are needed to explore how future conditions play out based on assumed decisions, policies, and environmental, social, and economic conditions. For example, a renewable energy project may define a scenario of increased energy contributions from solar, wind, and/or biomass and compare the potential social, environmental, and economic conditions to those that might result from a reference scenario defined by current conditions extended across the same time frame. Deciding what management options are considered and compared under each scenario should relate to stakeholder concerns as well as what is possible (Parish et al. 2017). Assumptions underlying scenarios should be documented and based on published sources, to the extent possible, to facilitate interpretation of results and replication of assessment parameters.

Targets for each indicator relate to the baseline conditions and scenarios being considered. Baseline information for each indicator provides a starting point from which to compare other information and can be derived from historical information, scientific literature, or measurements made before the assessment is implemented (when possible). Historical information is used to document recent trends and intra- or interannual variability and cycles, which may otherwise confound interpretation of indicator values.

\section{Determine indicator values}

Once a set of indicators and scenarios are selected and defined, indicator values need to be quantified for each scenario to allow stakeholders to compare the alternatives. Indicator values can be obtained through empirical measures or surveys of similar situations, model projections, expert opinion, or a combination of 
these sources. It is helpful to inform stakeholders about the means of collecting indicator values, and engage them in the process when possible, so that the results are transparent and understood by all concerned.

Reviews of diverse projects aiming for sustainable outcomes confirm that one of the most common challenges is timely access to reliable and useful information to guide decisions (e.g., Williams and Brown 2012; CMP 2013; Tarter et al. 2016; Eichler Inwood et al. 2018). When indicator values are estimated by models, it is important to use best available data for calibration (i.e., to adjust parameters to maximize agreement between observed data and the model's predictions) and validation (i.e., to compare model projections to independent data sets). Whenever future conditions are projected or counterfactual conditions are simulated via models, variability in estimated values and uncertainties in the underlying data and modeling should be documented (e.g., ASTM 2017).

Analyze trends and tradeoffs

Trends in selected indicators should consider linkages between the performance of the activity and affected variables. Documenting cause and effect via experiments and models is challenging (De Boeck et al. 2015). Correctly assigning attribution to certain practices takes time, knowledge, and resources (Efroymson et al. 2016). Methods to test the weight of evidence using different tools for causal analysis help distinguish the share of effects that is caused by the activity being assessed versus effects that are more reasonably attributed to other factors (Efroymson et al. 2016). Applying this process over time ultimately helps stakeholders to understand cause-and-effect relationships, which are at the core of most sustainability debates, and to identify improved practices.

Evaluating trade-offs involves the comparison of changes in indicator values under different scenarios (Fisher et al. 2011; King et al. 2013; Villa et al. 2014; Parish et al. 2016). Techniques used to evaluate tradeoffs include optimization approaches and algorithms for scenario comparison of indicator values. No matter what method is used, it is essential to share complete information on all indicators, potential trade-offs, and any underlying assumptions.
Managing trade-offs between potential benefits and negative impacts is challenging but necessary (Chapin et al. 2011; Kanter et al. 2018). Analysis of indicators under each scenario identifies environmental, social, and economic costs and benefits. Ultimately, choices must be made about what result is more desirable (e.g., greater profit or cleaner water). Ideally the evaluation process identifies costs and benefits across diverse metrics so that an informed decision can be made. Some tradeoffs may be avoided. For example, "win/ win" options avoid trade-offs by strategic crop placement across a landscape to produce multiple benefits simultaneously (Parish et al. 2012) such as improving water quality while increasing habitat suitable for pollinators (Graham et al. 2017).

\section{Identify good practices}

One goal of the iterative process (Fig. 1) is to identify and promote "good practices" for the activity being assessed. We prefer to call them good or better practices, rather than "best management practices (BMPs)," because what is "best" may transform over time as conditions change. The assessment should lead to identification and implementation of better practices for producing goods and managing the overall system in which the goods are produced while recognizing that good practices depend on a specific set of conditions and stakeholders at a given point in time. Recommended practices related to agricultural and forestry activities support better water quality, soil quality, and crop production. For example, good practices for harvesting wood products from forests include those that minimize soil disturbance and water quality impacts (Cristan et al. 2016). FAO (2012, 2018a, b) provides examples of good environmental practices for agricultural and forest production pertaining to soil, water, biodiversity, and climatechange mitigation, as well as the social and economic benefits to income, availability of inputs, and access to energy. While many industries have developed BMPs (Ice 2011; Seuring and Muller 2008), their further development is an active area of research (Youngs and Somerville 2014).

Examples of success, failure, and lessons learned are important to support a culture of continual learning and to better quantify risks as they become apparent (e.g., Seuring and Muller 2008; Lindenfeld et al. 2014). Good practices also consider preparation and 

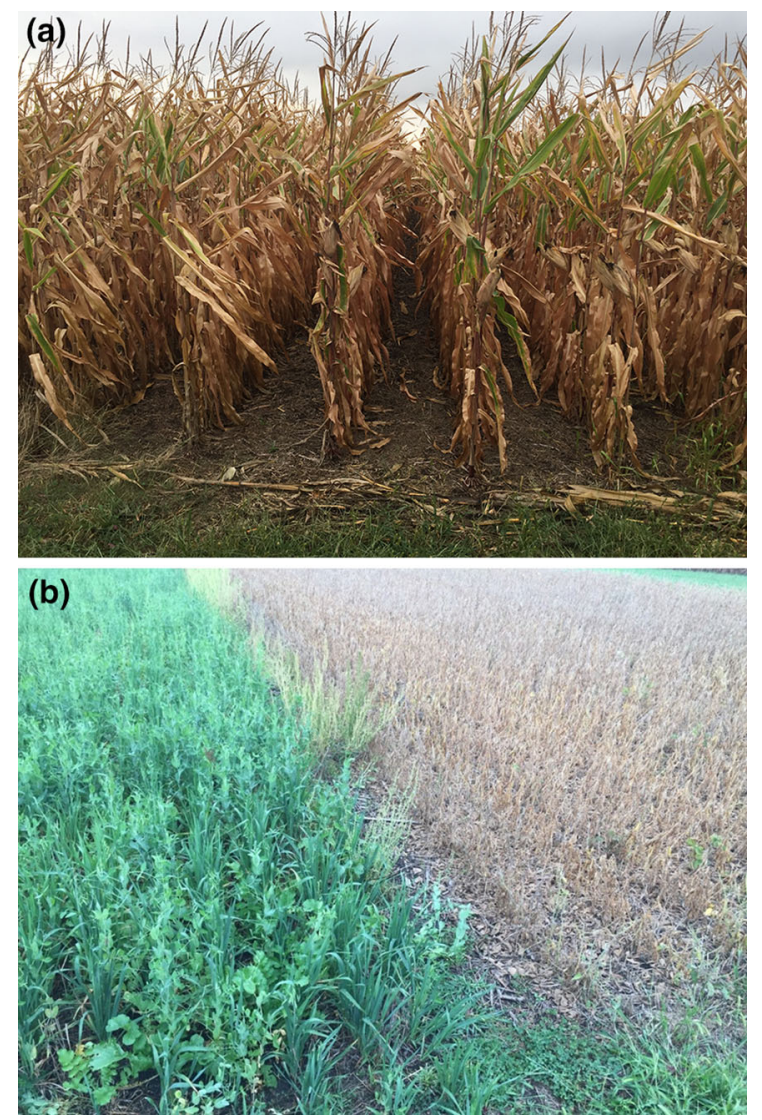

Fig. 3 By providing incentives to harvest a portion of residues from high-yielding fields that are used to produce biofuel, U.S. bioenergy production in Iowa (a) facilitates no-till corn production that reduces soil erosion and promotes the use of perennial and annual cover crops, which further reduce erosion and enhance soil carbon and other qualities. Another alternative (b) illustrates that erosion is reduced by cover crop mix (on the left) compared to a soybean monoculture (on the right) (photos by authors, September 2017)

early warning systems to reduce impacts from extreme events (drought, flood, fire, disease, economic downturns, political upheaval, etc.) (Dale et al. 2016). Development and implementation of good practices are supported by transparent and participatory monitoring as well as by the ability to adjust targets, interventions, and regulations in response to new knowledge (Dale et al. 2016).

\section{Insights from experience}

We have used this decision-making cycle (Fig. 1) to assess progress toward landscape sustainability goals
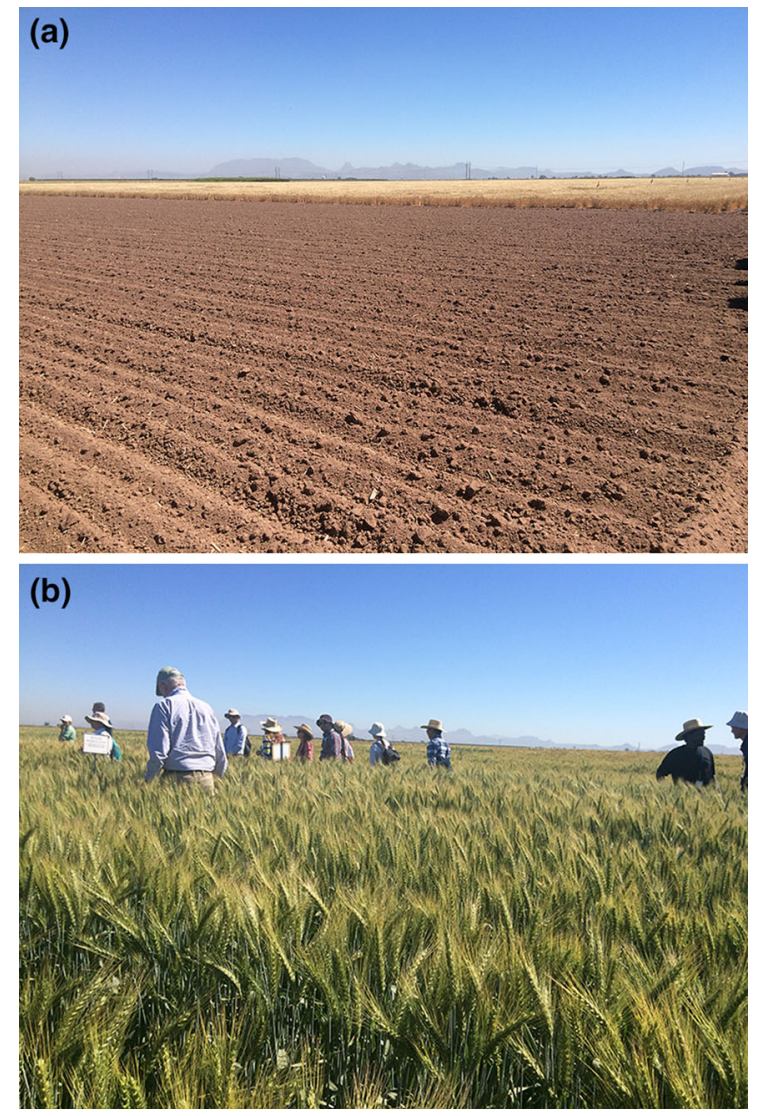

Fig. 4 Large-scale agriculture in the Yaqui Valley of Mexico (a) shortly after conventional tillage and planting and (b) mature wheat. See Case 2 for summary of Yaqui Valley case study. Photographs by authors, March 2017

for bioenergy (Case 1; Fig. 3) and row-crop agriculture (Case 2; Fig. 4). We suggest that this method has broad applicability for decision makers evaluating a variety of alternative pathways for production of food, fiber, feed, energy, and other goods required by human society as well as for practitioners interested in assessing progress toward established goals.

Case 1: Example of applying the landscape assessment approach to cellulosic-based bioenergy in the United States

Landscape sustainability is a major concern for bioenergy production. Multiple studies suggest that cellulosic feedstocks provide more sustainable and ethical energy options to society than fossil fuels but should be produced under designs that support ecosystem services as well as social and economic 
benefits (Robertson et al. 2008; Haughton et al. 2009; Buyx and Tait 2011; Dale et al. 2014) (Fig. 3). The environmental advantages are most evident when wastes and residues that would otherwise rot or be burned are used for bioenergy (Dale et al. 2014). Social benefits include enhanced food security, increasing rural employment opportunities, expanding the tax base that supports community services, and increased fuel efficiency with reduced greenhouse gas emissions and improved public health (Dale et al. 2014). Below is a description of the application of the six steps of assessing progress toward landscape sustainability (Fig. 1) to cellulosic bioenergy production.

(1) Define scope: The purpose of bioenergy sustainability assessment is to evaluate costs and benefits of bioenergy production and use compared to an alternative energy, typically fossil fuel. The spatial extent for bioenergy production focuses on the areas where biomass is grown or collected as well as where the energy is produced and used. Time steps are annual, and temporal horizons are on the order of years to decades depending on the indicators selected. The context or reference system refers to conditions without bioenergy production, which are often typical agriculture or forestry practices (e.g., Parish et al. 2017; Koponen et al. 2018).

(2) Prioritize indicators: A checklist of indicators in twelve categories was developed to reflect potential environmental (McBride et al. 2011) and socioeconomic (Dale et al. 2013) effects across the bioenergy production and use supply chain (Table 1). Nineteen environmental and sixteen socioeconomic categories of indicators provide a basis to quantify and evaluate effects of bioenergy systems across many regions where they are being deployed. Indicators relating to management performance are also useful. However, choosing the most appropriate indicators for a particular situation requires consideration of the specific project and stakeholder input (Efroymson et al. 2013; Dale et al. 2016). For instance, stakeholders in an Iowa project did not prioritize air quality indicators (Dale et al. 2018a), and a case study of east Tennessee switchgrass production identified the need to add "profit variability" as an indicator since switchgrass was less susceptible to volatility in yields and market prices than products of conventional agriculture (Parish et al. 2016).

(3) Establish targets: Targets are reasonably achievable values for each indicator affected by bioenergy production that would result in enhanced environmental, social, or economic conditions. For bioenergy systems, production targets were determined by the amount of biomass required by the refinery (e.g., Parish et al. 2012). Targets for stream nutrient concentration were set by using existing regulations or (in their absence) by potential thresholds of stream eutrophication (Dodds 2007). Baseline refers to conditions for each indicator that occur when bioenergy is not produced. Since bioenergy production often happens where agricultural or forest activities are ongoing, the baseline values are typically quite different from "natural" conditions.

(4) Determine indicator values: Documenting changes in indicator values over time or space when bioenergy is produced as compared to no bioenergy is challenging because production is limited. Information has been obtained from monitoring programs of the U.S. Department of Agriculture, field studies, and through comparison of modeled alternative scenarios (e.g., see Parish et al. 2012, 2016; Landis et al. 2018).

(5) Analyze trends and tradeoffs: Trends differ for each context. For example, when the bioenergy feedstock is a waste that otherwise might contribute to environmental degradation, benefits accrue. Use of perennial crops may improve ecosystem services (Cacho et al. 2018). When feedstock production occurs in rural areas where jobs are in decline, the bioenergy industry provides a boon to the economy and social structure. There are trade-offs among different scenarios in terms of overall area affected and the characteristics of ecosystems (e.g., Costanza et al. 2017), for landscape effects on wildlife habitat varies by species (e.g., Tarr et al. 2017). Displacement of carbon-intensive fossil fuels helps keep carbon in the ground and therefore reduce carbon emissions. When use of the biomaterial for energy is a small fraction compared to other uses, the effects are difficult to discern. A causal analysis approach and 
simulation models are useful in considering attribution of effects associated with bioenergy systems (Efroymson et al. 2016). Spider diagrams are a common means to display potential tradeoffs (e.g., Landis et al. 2018). We used a combination of techniques to visualize potential tradeoffs between profit and water quality resulting from different switchgrass planting configurations within a watershed (e.g., Parish et al. 2012). In that East Tennessee context, switchgrass production for bioenergy improved environmental and social sustainability conditions without adverse economic impacts, which enhanced landscape sustainability; however, achieving these benefits requires a strong bioenergy market (Parish et al. 2016).

(6) Identify good practices: Results confirm the benefits of using waste material when possible, following approved good management practices (e.g., Ice 2011; Williams and Brown 2012), conducting systematic monitoring and evaluation of potential effects to inform continual improvement of management practices, and relying on a network of transparent training and monitoring support to ensure accountability rather than a single program or metric.

Case 2: Example of applying the landscape assessment approach to integrated row crop agriculture in western Mexico

Evaluation of the agriculture systems in the Yaqui Valley of Mexico first focused on factors that affect yield (e.g., Luers et al. 2003). However, consideration of landscape sustainability in the region requires a broader perspective (Matson 2012; Matson et al. 2016). Application of the approach described in this paper (Fig. 1) to the systems that predominate production in the Yaqui Valley surrounding Obregon, Mexico (Fig. 4), requires consideration of the environmental, social, and economic implications of largescale farming (Eichler Inwood 2018). The application of the six steps of assessing progress toward landscape sustainability to large-scale agriculture in western Mexico is described below.

(1) Define scope: The purpose of the assessment is to determine the environmental, social, and economic implications of irrigated agriculture for the broader Yaqui River watershed. Major sustainability questions revolve around future implications of water management and effects on environmental and social conditions. The spatial extent is the area of the Yaqui Valley that is irrigated for row crops (predominantly wheat) and spans approximately 225,000 ha. Time steps of primary agricultural management decisions and data availability on most indicators are annual or by cropping season.

(2) Prioritize indicators: Indicators were selected from an initial checklist with input from stakeholders. Stakeholders included representatives from agriculture industries, commodity organizations, farmers' unions, local environmental research faculty, international researchers, farm owners, irrigation managers, plant pest and disease control specialists, agricultural outreach agents, and community members. The checklist proposed for sustainability indicators (Table 1) required modifications to reflect local contextual issues and availability of information. The 25 indicators that were selected are those deemed to be useful to diverse groups, technically effective for the location, practical in terms of obtaining indicator values, and sufficient but not exhaustive. These indicators were determined by ranking candidate indicators through a process of compiling expert opinions after consultation with several stakeholder groups (Eichler Inwood 2018). Seasonal availability of reservoir irrigation water and water quality were identified as top priorities in this desert region (Eichler Inwood 2018). Stakeholders also prioritize crop diversification and seed varieties that reduce vulnerabilities to extreme events and market fluctuations that are inherent under current practices where most land is planted in a single variety of wheat. In addition, stakeholders are interested in indicators that guide agricultural management practices toward higher profits, lower water demand, lower pesticide exposure, and reduced wastes. Indicators such as energy security and social acceptance were rated by local stakeholders as being less important than measures such as conservation of water and soil, nutrient management, resilience to extreme events, transparency, and equity. 


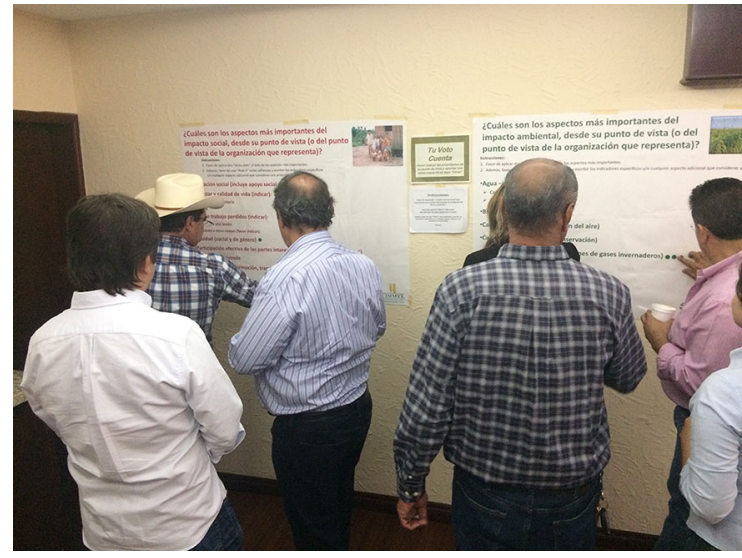

Fig. 5 Stakeholders were actively engaged in the evaluation of agriculture systems in the Yaqui Valley of Mexico by using interactive posters (Dale and Kline 2017). Stakeholder engagement is critical to each stage of the sustainability assessment process. Photograph by authors, March 2017

(3) Establish targets: Targets are being developed in consultation with stakeholders (Fig. 5) based on their perspectives on desired future conditions and review of current conditions and past trends that may suggest impending changes (Eichler Inwood 2018) as well as theories of change that identify strategies for meeting goals (Mayne and Johnson 2015; CIMMYT 2017). The reference conditions are those associated with prior cultivation practices or "business as usual" where about $80 \%$ of irrigated land is used for durum wheat (Triticum turgidum subsp. Durum) managed as a single-season monoculture.

(4) Determine indicator values: Of the 25 prioritized indicators, information is readily available for only 7 of them: soil quality (area of at-risk soils), productivity (measured by the Normalized Difference Vegetation Index, NDVI), biodiversity (protected area), vulnerability (government indices related to climate change), poverty (government index), transparency (Corruption Perceptions Index), and economic implications of crop diversity (Shannon diversity index by area and value of crops) (Eichler Inwood 2018). Baseline data for selected indicators are derived from information collected by local researchers or prior studies (e.g., Matson 2012; Matson et al. 2016) and models (e.g., for greenhouse gas emissions). The indicator values used are annual or seasonal data from 2015 to
2017 and earlier trend data when available. Data were accessed through archived national and international sources such as census data, agricultural records, and public satellite imagery (Eichler Inwood 2018).

(5) Analyze trends and tradeoffs: Recent trends are summarized by Eichler Inwood (2018). Whereas the region is highly productive, it is at risk of yield decline in areas with low soil quality. About half of the area contains the more desirable soils for agriculture, but the rest of the area is at risk of compaction or salinization. Areas under conservation agriculture practices have better physical properties, moisture retention capacity, and soil biota (Govaerts et al. 2006; Verhulst et al. 2011; Fuentes et al. 2012; Rivers et al. 2016). Peak productivity for winter crops in the Yaqui Valley tends to be in lateFebruary to mid-March. There are no habitat conservation areas within this agricultural valley, and hence native diversity is low; however planting of perennial crops could create more favorable habitat for some species (Asbjornsen et al. 2014). Transparency (as measured by perception of corruption) in the state has declined recently. Crop diversity has not changed in recent years and remains lower than that of a similarly productive climate in Southern California. Risk of drought and pest susceptibility related to low crop diversity are prevailing concerns.

(6) Identify good practices: The analyses suggest that there is an opportunity for improvement of soils through conservation agriculture techniques especially for soils at risk of compaction or salinization (Eichler Inwood 2018). The exchanges with stakeholders identified several promising practices including drip irrigation systems, improved management of nitrogen fertilizer and pesticides, and alternative production systems involving small animals, greenhouses, aquaculture, and planting new crop varieties. For example, farmers in the valley are experimenting with over 65 different crops ranging from walnuts to asparagus (Asparagus officinalis). Although new technologies, crops, and practices help achieve goals, this example also highlights the important roles played by policy, regulations, field-level monitoring, and 
enforcement of local regulations. If these aspects of governance do not provide the incentives needed to conserve water and avoid water contamination, then technical assistance to promote new crops and technologies may be for naught. Farmers are likely to do what is easiest and continue the same practices that they already know and consider less risky. However, making crop insurance available may encourage farmers to increase cropping diversity and thereby reduce the economic risk associated with crop loss.

\section{Overarching themes}

Our experiences in developing and testing this approach have led to the identification of several overarching and inter-connected themes (shown in the center of Fig. 1) that are critical for success when applying each step of the process, namely stakeholder engagement, transparency and trust, communication, monitoring, and continual improvement. Each of these themes is described below. We also identify some common pitfalls encountered when implementing the process and provide recommendations for minimizing costs and delays.

\section{Stakeholder engagement}

Stakeholder involvement (Beier et al. 2016; Djenontin and Meadow 2018; Petersen et al. 2018) underlies all aspects of this landscape sustainability assessment approach and helps build local capacities. Stakeholders should be a part of every step, for they form part of the context and are the key to bridging the "practitioner-researcher divide," which deters adoption of sustainability approaches (Rasmussen et al. 2017). Early and ongoing stakeholder engagement in defining desired future conditions, prioritizing practical indicators, and setting realistic goals determines success or failure of both the assessment and progress toward landscape sustainability (e.g., see Tarter et al. 2016; Rasmussen et al. 2017). Stakeholders also play critical roles in defining priorities based on the landscape context and in implementing good management practices (Johnson et al. 2003; Ness et al. 2007; Sydorovych and Wossink 2008; Cebrián-Piquerasa et al. 2017). For example, when asked to prioritize indicators, stakeholder often communicate their values and insights, as well as provide examples of how to measure progress, thereby helping to identify pertinent indicators (e.g., see Dale et al. 2018a). Therefore, the coordinator should take the time required for stakeholder engagement in planning and implementation of the assessment.

However, diverse perspectives from stakeholders also make it difficult to reach consensus on clear goals and a manageable number of indicators. From the outset of an assessment, it is often evident that some stakeholders have conflicting goals for the outcome. Developing consensus on well-defined and focused goals is critical because goals that are ambiguous or too broad result in the measurement of variables that are misleading or inaccurate, overly broad scopes, or targeting too many objectives (Tarter et al. 2016). It may be easier to reach consensus about what stakeholders don't want to happen, i.e., undesired future scenarios and changes to be avoided, rather than specific targets to be achieved (Zenner 2016). Stakeholder ownership of the process and results is instrumental in supporting long-term efforts to identify improved practices based on the signals provided by indicators.

Because participation of stakeholders results in a process that is not as neat and simple as idealized in Fig. 1, our recommendation is to work on several of the steps concurrently but to complete them in the order shown. Unexpected detours, hurdles, and delays are the norm and represent an important part of colearning and capacity building (e.g., Petersen et al. 2018; Williams and Brown 2012) in adaptive management. Nevertheless, it is advisable to revisit steps if new information or changing circumstances affect the activity, especially when such practices increase trust and local ownership of the process.

\section{Transparency and trust}

Transparency refers to sharing of all aspects of the assessment process including the methods used to establish goals and objectives, indicators, baselines, and targets as well as the information obtained (Cash et al. 2003). The assessment process requires trust founded on transparency including who is behind the activity and why, what kind of information is collected, and how that information is vetted, interpreted, and communicated. The inclusion of all key 
stakeholders is an essential part of transparency. Too often, native people, absentee owners, low income owners, renters, minorities, and those who are affected but are distant from the activity are not included in the evaluation. It may be useful to find multiple avenues of engaging stakeholders (e.g. through open discussions or focus groups, as well as semi-anonymous or closed surveys) so that literacy or language barriers can be addressed and community hierarchies or security concerns do not override expression of conflicting landscape goals.

Trust is a measure of confidence in the reliability and truthfulness of information and in the ability for the process to achieve desired results. Trust is essential for the process to fulfill its purpose in guiding decisions toward improved conditions. If stakeholders do not trust the process, the results have little value. Being open and transparent builds trust, but, particularly for outsiders, it is difficult to establish trust within assessment time frames. Hence it is useful to engage leaders and coordinators who have earned local respect.

Applying the framework (Fig. 1) at the inception provides an explicit commitment to transparency that increases legitimacy and helps build supportive constituencies for subsequent steps in the activity's development. Up-front investments to engage stakeholders pay off in the long run, for developing trust and good working relationships provides a pathway to leveraging the resources of other participates (Petersen et al. 2018). We recommend that the process be built on honesty and commitment to listening and sharing.

\section{Communication}

Transparent communication about available resources, developing consensus with stakeholders around a "doable" scope of work, and developing practical timelines with sufficient flexibility or a cushion that allows for unforeseen delays are important for success and reduce unrealistic expectations. Effective and timely communicating of information that helps guide decisions is key to making scientific assessments relevant to pending decisions and changes in policy (Lindenfeld et al. 2014, Kanter et al. 2018). Monitoring data and analyses should be shared in a timely fashion so that stakeholder decisions, actions, and opinions are based on current information (Palmer et al. 2005). To minimize misunderstandings, it is critical to ensure that terminology is explicitly defined and accepted by local stakeholders.

For landscapes that support production systems (such as agriculture and forestry), the iterative process in Fig. 1 entails sharing information about how progress toward established goals can be enhanced (or deterred) at all points along a value chain [e.g., procurements and supply chains, training and education, value proposition, outreach, quality control, and management systems as discussed in International Organization for Standardization (ISO) management system standards 14,001 and 90,001 (ISO 2018)]. New information and new contextual conditions result in new questions about how to better achieve goals, thereby continuing the assessment cycle.

The diversity of stakeholders in any one landscape means that diverse communication tools should be adopted. New technologies that provide information and feedback via the web or mobile applications have transformed the speed and ease with which information is shared (Nghiem and Carrasco 2016). However, it is challenging to authenticate the validity of information. While the internet provides an effective means to relay information to some groups, it does not work for all. Surveys and citizen science are effective ways to collect information as well as share information about the assessment. Often it is necessary for the assessment coordinator to reach out to individual stakeholders to ensure that all relevant groups are involved in the assessment process (e.g., Dale et al. 2018a).

Because of the underlying complexity of sustainability and its many dimensions, visualization is an essential part of communication. Visualization involves translating complex information about the landscape into a graph, diagram, or images to facilitate understanding. Tufte (1983) notes that visualizations should provide the data and encourage the viewer to think about the meaning of the information rather than about methods used to collect it or the graphic design. Effective visualization transforms large amounts of information in a manner that allows users to capture the big picture or zoom into different levels of detail (Tufte 1983; Dale and Kline 2017). Visualization tools may use a combination of graphical, statistical, and verbal descriptions. Integrating information for effective visualization of indicator trends is necessary for stakeholders to better understand progress toward 
established goals and any potential tradeoffs and synergies.

We recommend that procedures for data collection, monitoring, and sharing of data and analytical results should be clearly documented early in the process and understood by all concerned (Dale et al. 2016). Special attention needs to be paid to data aggregation, any procedure by which information is expressed in a summary form for purposes such as reporting or analysis. As data are aggregated, the risks for errors, misinterpretation, omission, or misrepresentation increase. For example, if data on environmental qualities are aggregated, progress in improving one aspect, such as air quality, could mask a critical decline in quality for another aspect, such as water or biodiversity. Or improvements in one watershed could mask deteriorating water qualities in another area. Consolidated scores based on off-setting values is described as a "weak" method for measuring effects compared to "strong" approaches where each indicator is assessed and reported individually (Pearce et al. 1994; Rickels et al. 2016). Mathematically valid approaches for aggregation provide criteria for selection of functions to combine information, which are often necessary when collating data for a landscape sustainability assessment (Pollesch and Dale 2015).

\section{Monitoring}

Ongoing data collection programs are another challenging but essential cross-cutting theme. Decisions about what data to obtain should be guided by identifying information that is relevant, timely, and at an appropriate scale. Monitoring data are gathered by governmental agencies, citizen science, civil society organizations, or industry. While government measurement programs do not always focus on stakeholders' issues, they are often the best option available for gathering consistent and statistically valid data [e.g., the U.S. Department of Agriculture's Forest Inventory and Analysis (https:// www.fia.fs.fed.us), the Conservation Effects Assessment Project (https://www.nrcs.usda.gov/wps/portal/ $\mathrm{nrcs} / \mathrm{main} /$ national/technical/nra/ceap/), or the Cropland National Assessment (https://www.nrcs.usda.gov/ wps/portal/nrcs/detail/national/technical/nra/ceap/na/ ?cid=nrcs143_014144)]. Information collected by citizens groups or non-governmental organizations is valuable and typically focuses on a particular concern, place, and time. Such snapshots can be accurate and important as reference points, particularly if data collection and documentation are guided by professionals (Tredick et al. 2017). Reports that arise from photographs, anecdotes, or the internet should be validated and confirmed by authoritative sources. Industries affected by or affecting system conditions often collect their own information as required by permits or for their edification-but these data are not always available to or understandable by the public. All sources of monitoring information are useful, but each source must be interpreted carefully by considering the purpose, protocols, time, place, sampling methods, etc. to determine representativeness and statistical validity.

While the tendency is to seek out as much information as possible and to identify all ideal indicators, our recommendation is to use available data when possible and to focus on a few key measures that reveal trends or portend changes in conditions of highest priority to stakeholders. We find it useful to start with defined categories and checklists of potential indicators that reflect environmental, social, and economic concerns (e.g., Table 1). This approach allows stakeholders to question the terms and their meaning and often results in a lively discussion and reevaluation of indicators and their definition. The future health of ecosystems and human well-being should be considered (Collins et al. 2011), and, as conditions change, checklists must be modified to reflect stakeholder concerns about environmental, social, and economic outcomes. Indicators that are not priorities for stakeholders should be considered for removal (e.g., Dale et al. 2018a), and context-specific priorities might necessitate the addition of one or more indicators to the initial check list (e.g., Case 2).

\section{Continual improvement}

A focus on continual improvement is recommended, for it helps an activity adapt to ever-changing economic, political, social, and environmental conditions, including extreme weather events and disturbance regimes (Dale et al. 2018b). There is no "silver bullet" to achieve landscape sustainability goals but rather many small steps that move an activity closer to goals over time. Thus, continual improvement is commonly adopted by standards and certification schemes (e.g., GBEP 2011; ISO 2015; RSB 2016; ASTM 2017). Adaptive management that promotes 
continual improvement is a widely recognized means to promote more sustainable resource management (Williams and Brown 2012).

Systematic monitoring to determine progress toward indicator targets and analysis to relate changes to activity interventions may result in discarding some indicators that are not helpful or revising how indicators are measured and interpreted based on new understanding. Historical data are limited, and knowledge of the future is uncertain, but as new information is gathered, new challenges and opportunities for improvement arise. The assessment process should be updated based on new understanding about the costs and benefits of available options.

Assessment developers need to allocate sufficient resources for science-based analysis to foster learning with and among stakeholders (Petersen et al. 2018). Efforts to guide decisions toward continual improvement will be fruitful only if people understand why changes in practices are necessary for the achievement of desirable outcomes.

\section{Conclusions}

Implementing this process to assess progress toward landscape sustainability entails significant resources (e.g., staff time, money, and multi-disciplinary skill sets that are difficult to assemble and maintainincluding a team capable of effective outreach and who are perceived as being honest brokers). Each assessment involves unique opportunities and constraints. Deployment requires time for discussion, comprehension, and evaluation of goals, indicators, changing circumstances, tradeoffs, and ways to improve practices. To achieve established goals with limited resources requires creativity, partnerships, and identifying local champions who are respected and enthusiastic about those goals. With good planning and local collaborators, we find it is possible to engage stakeholders in defining goals, indicators, and targets. For example, low-cost efforts with high returns include taking advantage of existing meetings and extension agent activities, employing simple tools such as interactive posters, literature reviews, and outreach to partners to collect available data. Combining these inputs with strategic interviews to fill gaps in representation, we have been able to generate preliminary quantitative and qualitative results that could be refined with further stakeholder input.

Our experience is that engaging in this assessment approach supports adoption of better landscape management practices via adaptive management and a process involving transdisciplinary research. Viewing landscape sustainability assessment as an ongoing process emphasizes local social and institutional mechanisms to identify and adapt good practices to continually improve outcomes over time. Stakeholder engagement in, and ultimate ownership of, the process is more important than a specific result or indicator value. While idealized goals may or may not be achieved, the assessment approach described in this manuscript provides a means to build capacities to assess environmental, social, and economic patterns and processes that are important to local stakeholders. Flexibility and a willingness to respond to input by adjusting assessment plans and goals, patience on the part of all parties, and a long-term commitment to the iterative process are also important qualities for successful assessment involving stakeholders.

Just as sustainability is not a final state to be achieved, the assessment process does not provide a final answer that assures a landscape is sustainable. Experience suggests that ongoing monitoring and evaluation yield new insights and, sometimes, unexpected information. Working through this landscape assessment approach leads to discoveries and new questions that may require reevaluation of goals or stepping back to restart the assessment. This process supports the role of researchers and scientists to provide training, data, and analytical support to local stakeholders. The ultimate goal is to be facilitators, helping to transparently compare alternatives, identify good practices, and guide subsequent decisions toward ever-improving outcomes.

Acknowledgements Dale's initial work on the approach was funded by a contract from the Strategic Environmental Research and Development Program (SERDP) Project CS-1259 to Oak Ridge National Laboratory (ORNL). Dale and Parish were also supported by the ORNL Laboratory Directed Research and Development. Kline's research includes field work in twelve developing countries from 1980 to 2008 supported by the U.S. Agency for International Development. The U.S. Department of Energy (DOE) Bioenergy Technologies Office supported recent research to refine the approach and prepare this manuscript. In addition, support from the IEA Bioenergy Task 43 "Biomass feedstock for energy markets" is gratefully acknowledged. The Yaqui Valley case study mentioned in the paper was funded by 
the International Maize and Wheat Improvement Center (CIMMYT) and the U.S. Agency for International Development. ORNL is managed by the UT-Battelle, LLC, for the U.S. Department of Energy under contract DE-AC0500OR22725. ORNL researcher Yetta Jager provided useful comments on an earlier version of this manuscript.

Open Access This article is distributed under the terms of the Creative Commons Attribution 4.0 International License (http:// creativecommons.org/licenses/by/4.0/), which permits unrestricted use, distribution, and reproduction in any medium, provided you give appropriate credit to the original author(s) and the source, provide a link to the Creative Commons license, and indicate if changes were made.

\section{References}

Anseeuw W, Wily LA, Cotula L, Taylor M (2012) Land rights and the rush for land. Findings of the global commercial pressures on land research project. International Land Coalition, Rome, Italy. www.landcoalition.org. Accessed 24 May 2019

Asbjornsen H, Hernandez-Santana V, Liebman M, Bayala J, Chen J, Helmers M, Ong CK, Schulte LA (2014) Targeting perennial vegetation in agricultural landscapes for enhancing ecosystem services. Renew Agric Food Syst 29:101-125

Ashok S, Tewari HR, Behera MD, Majumdar A (2017) Development of ecotourism sustainability assessment framework employing Delphi, C\&I and participatory methods: a case study of KBR, West Sikkim, India. Tour Manag Perspect 21:24-41

ASTM International E3066-16a (2017) Standard practice for assessing the relative sustainability involving energy or chemicals from biomass. https://www.astm.org/Standards/ E3066.htm. Accessed 24 May 2019

Bailis R, Baka J (2011) Constructing sustainable biofuels: governance of the emerging biofuel economy. Ann Assoc Am Geogr 101(4):827-838

Beardsley TM (2011) Trust and action. BioScience 61:171-171

Beier P, Hansen L, Hellbrecht LJ, Behar D (2016) A how-to guide for coproduction of actionable science. Conserv Lett 10:288-296

Buyx A, Tait J (2011) Ethical framework for biofuels. Science 332(6029):540-541

Cacho J, Negri M, Zumpf C, Campbell P (2018) Introducing perennial biomass crops into agricultural landscapes to address water quality challenges and provide other environmental services. Wiley Interdiscip Rev 7(2):e275

Cairns J, McCormick PV, Niederlehner BR (1993) A proposed framework for developing indicators of ecosystem health. Hydrobiologia 263:1-44

Carlsson L, Callaghan E, Morley A, Broman G (2017) Food system sustainability across scales: a proposed local-toglobal approach to community planning and assessment. Sustainability. https://doi.org/10.3390/su9061061

Cash D, Clark WC, Alcock F, Dickson NM, Eckley N, Jäger J (2003) Salience, credibility, legitimacy and boundaries: linking research, assessment and decision making. KSG working papers series. https://www.bing.com/search?q= Cash $\% 20$ Triumvirate $\% 20$ of $\% 20$ slience $\% 2 \mathrm{C} \% 20$ credibility $\% 20$ and $\% 20$ legitimacy $\& p c=c o s p \& p t a g=$ G6C999N1234D0 90118A98C4AF66BD\&form $=$ CONBDF \& conlogo $=$ CT32 1 0127. Accessed 21 May 2019

Cebrián-Piquerasa MA, Karraschb L, Kleyera M (2017) Coupling stakeholder assessments of ecosystem services with biophysical ecosystem properties reveals importance of social contexts. Ecosyst Serv 23:108-115

Chapin FS, Power ME, Pickett STA, Freitag A, Reynolds JA, Jackson RB, Lodge DM, Duke C, Collins SL, Power AG, Bartuska A (2011) Earth Stewardship: science for action to sustain the human-earth system. Ecosphere 2:1-20

CIMMYT (2017) Theory of change [WWW document]. http:// maize.org/theory-of-change/. Accessed 22 May 2019

Collins SL, Carpenter SR, Swinton SM, Orenstein DE, Childers DL, Gragson TL, Grimm NB, Grove JM, Harlan SL, Kaye JP, Knapp AK, Kofinas GP, Magnuson JJ, McDowell WH, Melack JM, Ogden LA, Robertson GP, Smith MD, Whitmer AC (2011) An integrated conceptual framework for long-term social-ecological research. Front Ecol Environ 9:351-357

Conservation Measures Partnership (CMP) (2013) Open Standards for the Practice of Conservation Ver.3. http://www. conservationmeasures.org/about-cmp/. Accessed 24 May 2019

Costanza JK, Abt RC, McKerrow AJ, Collazo JA (2017) Bioenergy production and forest landscape change in the southeastern United States. Glob Chang Biol Bioenergy 9(5):924-939

Cristan R, Aust WM, Bolding MC, Barrett SM, Munsell JF, Schilling E (2016) Effectiveness of forestry best management practices in the United States: literature review. For Ecol Manag 360:133-151

Dale VH, Beyeler SC (2001) Challenges in the development and use of ecological indicators. Ecol Ind 1:3-10

Dale VH, Kline KL (2017) Interactive Posters: a valuable means for enhancing communication and learning about productive paths toward sustainable bioenergy. Biofuels Bioprod Biorefin 11:243-246

Dale VH, Efroymson RA, Kline KL, Langholtz MH, Leiby PN, Oladosu GA, Davis MR, Downing ME, Hilliard MR (2013) Indicators for assessing socioeconomic sustainability of bioenergy systems: a short list of practical measures. Ecol Ind 26:87-102

Dale B, Anderson J, Brown R, Csonka S, Dale VH, Herwick G, Jackson R, Jordan N, Kaffka S, Kline K, Lynd L, Malmstrom C, Ong R, Richard T, Taylor C, Wang M (2014) Take a closer look: biofuels can support environmental, economic and social goals. Environ Sci Technol 48:7200-7203

Dale VH, Efroymson RA, Kline KL, Davitt M (2015) A framework for selecting indicators of bioenergy sustainability. Biofuels Bioprod Biorefin 9:435-446

Dale VH, Kline KL, Buford MA, Volk TA, Smith CT, Stupak I (2016) Incorporating bioenergy into sustainable landscape designs. Renew Sustain Energy Rev 56:1158-1171

Dale VH, Kline KL, Richard TL, Karlen DL, Belden WW (2018a) Bridging biofuel sustainability indicators and 
ecosystem services through stakeholder engagement. Biomass Bioenergy 114:143-156

Dale VH, Jager HI, Wolfe AK, Efroymson RA (2018b) Risk and resilience in an uncertain world. Front Ecol Environ 16:3

De Boeck HJ, Vicca S, Roy J, Nijs I, Milcu A, Kreyling J, Jentsch A, Chabbi A, Campioli M, Callaghan T, Beierkuhnlein C, Beier C (2015) Global change experiments: challenges and opportunities. BioScience 65:922-931

Djenontin INS, Meadow AM (2018) The art of co-production of knowledge in environmental sciences and management: lessons from international practice. Environ Manag 61:885-903

Dodds WK (2007) Trophic state, eutrophication and nutrient criteria in streams. TREE 22(12):669-676

EcoLabel Index (2018) As of July 2018, the Eco-Label Index was tracking 463 distinct eco-labels listed at http://www. ecolabelindex.com/. Accessed 24 May 2019

Efroymson RA, Dale VH, Kline KL, McBride AC, Bielicki JM, Smith RL, Parish ES, Schweizer PE, Shaw DM (2013) Environmental indicators of biofuel sustainability: what about context? Environ Manag 51:291-306

Efroymson RA, Kline KL, Angelsen A, Verburg PH, Dale VH, Langeveld JWA, McBride A (2016) A causal analysis framework for land-use change and the potential role of bioenergy policy. Land Use Policy 59:516-527

Eichler Inwood SE (2018) Improving sustainability of agricultural landscapes through assessment and adaptive management. PhD Dissertation. The University of Tennessee, Knoxville

Eichler Inwood SE, López-Ridaura S, Kline KL, Gérard B, Monsalue AG, Govaerts B, Dale VH (2018) Assessing sustainability in agricultural landscapes: a review of approaches. Environ Rev 26:299-315

Fisher B, Turner RK, Burgess ND, Swetnam RD, Green J, Green RE, Kajembe G, Kulindwa K, Lewis SL, Marchant R, Marshall AR (2011) Measuring, modeling and mapping ecosystem services in the Eastern Arc Mountains of Tanzania. Prog Phys Geogr 35:595-611

Food and Agricultural Organization (FAO) (2014) FAO's Bioenergy and Food Security (BEFS) approach: implementation guide. ISBN 978-92-5-108222-5. http://www. fao.org/docrep/019/i3672e/i3672e.pdf. Accessed 24 May 2019

Food and Agriculture Organization (FAO) (2012) Good environmental practices in bioenergy feedstock production: making bioenergy work for climate and food security. FAO Environment and Natural Resources Working Paper No. 49, Rome, Italy. http://www.fao.org/3/i9037en/I9037EN. pdf. Accessed 24 May 2019

Food and Agriculture Organization (FAO) (2018a) The 10 elements of agroecology: guiding the transition to Sustainable food and agricultural systems. Rome, Italy

Food and Agriculture Organization (FAO) (2018b) Sustainable farming systems for food and nutrition security: Global forum on food security and nutrition. FSN Forum, Rome, Italy. http://www.fao.org/3/i8603en/I8603EN.pdf

Fuentes M, Hidalgo C, Etchevers J, de León F, Guerrero A, Dendooven L, Verhulst N, Govaerts B (2012) Conservation agriculture, increased organic carbon in the top-soil macro-aggregates and reduced soil $\mathrm{CO}_{2}$ emissions. Plant Soil 355(1-2):183-197

Galik CS, Abt RC (2016) Sustainability guidelines and forest market response: an assessment of European Union pellet demand in the southeastern United States. Glob Chang Biol Bioenergy 8:658-669

Garrick DE, Hall JW, Dobson A, Damania R, Grafton RQ, Hope R, Hepburn C, Bark R, Boltz F, De Stefano L, O’Donnell E, Matthews N, Money A (2017) Valuing water for sustainable development: measurement and governance must advance together. Science 358:1003-1005

Genovese A, Morris J, Piccolo C, Koh SCL (2017) Assessing redundancies in environmental performance measures for supply chains. J Clean Prod 167:1290-1302

Global Bioenergy Partnership (GBEP) (2011) The global bioenergy partnership sustainability indicators for bioenergy. Food and Agricultural Organization of the United Nations (FAO), Climate, Energy and Tenure Division, Rome, Italy. http://www.globalbioenergy.org/fileadmin/ user_upload/gbep/docs/Indicators/The_GBEP_Sustainabi lity_Indicators_for_Bioenergy_FINAL.pdf. Accessed 24 May 2019

Govaerts B, Sayre KD, Deckers J (2006) A minimum data set for soil quality assessment of wheat and maize cropping in the highlands of Mexico. Soil Tillage Res 87(2):163-174

Graham JB, Nassauer JI, Currie WS, Ssegane H, Negri MC (2017) Assessing wild bees in perennial bioenergy landscapes: effects of bioenergy crop composition, landscape configuration, and bioenergy crop area. Landscape Ecol 32:1023-1037

Haughton AJ, Bond AJ, Lovett AA, Dockerty T, Sünnenberg G, Clark SJ, Bohan DA, Sage RB, Mallott MD, Mallott VE, Cunningham MD, Riche AB, Shield IF, Finch JW, Turner MM, Karp A (2009) A novel, integrated approach to assessing social, economic and environmental implications of changing rural land use: a case study of perennial biomass crops. J Appl Ecol 46:315-322

Heink U, Kowarik I (2010) What are indicators? On the definition of indicators in ecology and environmental planning. Ecol Ind 10:584-593

Hunter MC, Smith RG, Schipanski ME, Atwood LW, Mortensen DA (2017) Agriculture in 2050: recalibrating targets for sustainable intensification. BioScience 67:385-390

Iacovidou E, Velis CA, Purnell P, Zwirner O, Brown A, Hahladakis J, Millward-Hopkins J, Williams PT (2017) Metrics for optimising the multi-dimensional value of resources recovered from waste in a circular economy: a critical review. J Clean Prod 166:910-938

Ice GG (2011) Assessing best management practices effectiveness at the watershed scale. Appl Eng Agric 27:925-931

International Organization for Standardization (ISO) 13065 (2015) Sustainability criteria for bioenergy. International Organization for Standardization, Paris. http://www.iso. org/iso/home/store/catalogue_tc/catalogue_detail.htm?csn umber $=52528$. Accessed 24 May 2019

International Organization for Standardization (ISO) (2018) Management system standards. International Organization for Standardization, Paris. https://www.iso.org/ management-system-standards.html Accessed 24 May 2019 
Johnson NL, Lilja N, Ashby JA (2003) Measuring the impact of user participation in agricultural and natural resource management research. Agric Syst 78:287-306

Jordan NR, Davis AS (2015) Middle-way strategies for sustainable intensification of agriculture. BioScience 65:513-519

Kanter DR, Musumba M, Wood SLR, Palm C, Antle J, Balvanera $\mathrm{P}$, Dale VH, Havlik P, Kline KL, Scholes RJ, Thornton P, Tittonell P, Andelman S (2018) Evaluating agricultural trade-offs in the age of sustainable development. Agric Syst 163:73-88

King JS, Ceulemans R, Albaugh JM, Dillen SY, Domec JC, Fichot R, Fischer M, Leggett Z, Sucre E, Trnka M, Zenone $\mathrm{T}$ (2013) The challenge of lignocellulosic bioenergy in a water-limited world. BioScience 63:102-117

Koponen K, Soimakallio S, Kline KL, Cowie A, Brandão M (2018) Quantifying the climate effects of bioenergy-choice of reference system. Renew Sustain Energy Rev 81:2271-2280

Landis DA, Gratton C, Jackson RD, Gross KL, Duncan DS, Liang C, Meehan TD, Robertson BA, Schmidt TM, Stahlheber KA, Tiedje JM, Werling BP (2018) Biomass and biofuel crop effects on biodiversity and ecosystem services in the north Central US. Biomass Bioenergy 114:18-29

Landres PB, Verner J, Thomas JW (1988) Ecological uses of vertebrate indicator species: a critique. Conserv Biol 2:316-328

Levin S (2013) The mathematics of sustainability. Not Am Math Soc 60:393-394

Lindenfeld L, Smith HM, Norton T, Grecu NC (2014) Risk communication and sustainability science: lessons from the field. Sustain Sci 9:119-127

Lindenmayer DB, Margules CR, Botkin DB (2000) Indicators of biodiversity for ecological sustainable forest management. Conserv Biol 14:941-950

Liu J, Hull V, Batistella M, DeFries R, Dietz T, Fu F, Hertel TW, Izaurralde RC, Lambin EF, Li S, Martinelli LA, McConnell WJ, Moran EF, Naylor R, Ouyang Z, Polenske KP, Reenberg A, de Miranda Rocha G, Simmons CS, Verburg PH, Vitousek PM, Zhang F, Zhu C (2013) Framing sustainability in a telecoupled world. Ecol Soc 18(2):26

Liu J, Mooney H, Hull V, Davis SJ, Gaskell J, Hertel T, Lubchenco J, Seto KC, Gleick P, Kremen C, Li S (2015) Systems integration for global sustainability. Science 347:1258832

Luers AL, Lobell DB, Sklar LS, Addams CL, Matson PA (2003) A method for quantifying vulnerability, applied to the agricultural system of the Yaqui Valley, Mexico. Glob Environ Chang 13:255-267

Matson PA (2012) Seeds of Sustainability: Lessons from the Birthplace of the Green Revolution. In: Pamela A (ed) Matson, 1st edn. Island Press, Washington, D.C.

Matson PA, Clark WC, Andersson K (2016) In: Matson PA, Clark WC, Andersson K (eds) Pursuing sustainability, 1st edn. Princeton University Press, Princeton

Mayne J, Johnson N (2015) Using theories of change in the CGIAR research program on agriculture for nutrition and health. Evaluation 21:407-442

McBride A, Dale VH, Baskaran L, Downing M, Eaton L, Efroymson RA, Garten C, Kline KL, Jager H, Mulholland
P, Parish E, Schweizer P, Storey J (2011) Indicators to support environmental sustainability of bioenergy systems. Ecol Ind 11:1277-1289

Miller TR, Wiek A, Sarewitz D, Robinson J, Olsson L, Kriebel D, Loorbach D (2014) The future of sustainability science: a solutions-oriented research agenda. Sustain Sci 9:239-246

Moldan B, Janoušková S, Hák T (2012) How to understand and measure environmental sustainability: indicators and targets. Ecol Indic 17:4-13

Muneepeerakul R, Castillo-Chavez C (2015) Toward a quantitative science of sustainability. Bull Math Biol 77:254-258

Musacchio LR (2013) Key concepts and research priorities for landscape sustainability. Landscape Ecol 28:995-998

Ness B, Urbel-Piirsalu E, Anderberg S, Olsson L (2007) Categorising tools for sustainability assessment. Ecol Econ 60:498-508

Nghiem TPL, Carrasco LR (2016) Mobile applications to link sustainable consumption with impacts on the environment and biodiversity. BioScience 66:384-392

Opdam P, Luque S, Nassauer J, Verburg PH, Wu J (2018) How can Landscape Ecol contribute to sustainability science? Landscape Ecol 33:1-7

Palmer MA (2012) Socioenvironmental sustainability and actionable science. BioScience 62:5-6

Palmer MA, Bernhardt ES, Chornesky EA, Collins SL, Dobson AP, Duke CS, Gold BD, Jacobson RB, Kingsland SE, Kranz RH, Mappin MJ, Martinez ML, Micheli F, Morse JL, Pace ML, Pascual M, Palumbi SS, Reichman O, Townsend AR, Turner MG (2005) Ecological science and sustainability for the 21st century. Front Ecol Environ 3:4-11

Parish ES, Hilliard M, Baskaran LM, Dale VH, Griffiths NA, Mulholland PJ, Sorokine A, Thomas NA, Downing ME, Middleton R (2012) Multimetric spatial optimization of switchgrass plantings across a watershed. Biofuels Bioprod Biorefin 6:58-72

Parish ES, Dale VH, English BC, Jackson SW, Tyler DD (2016) Assessing multimetric aspects of sustainability: application to a bioenergy crop production system in East Tennessee. Ecosphere 7(2):e01206

Parish ES, Dale VH, Kline KL, Abt RC (2017) Reference scenarios for evaluating wood pellet production in the Southeastern United States. Wiley Interdiscip Rev 6:e259

Pearce DW, Atkinson GD, Dubourg WR (1994) The economics of sustainable development. Annu Rev Energy Environ 19(1):457-474

Pearson DM, McAlpine CA (2010) Landscape Ecol: an integrated science for sustainability in a changing world. Landscape Ecol 25:1151-1154

Petersen B, Aslan C, Stuart D, Beier P (2018) Incorporating social and ecological adaptive capacity into vulnerability assessments and management decisions for biodiversity conservation. BioScience 68(5):371-380

Pollesch N, Dale VH (2015) Applications of aggregation theory to sustainability assessment. Ecol Econ 114:117-127

Rasmussen LV, Bierbaum R, Oldekop JA, Agrawal A (2017) Bridging the practitioner-researcher divide: indicators to track environmental, economic, and sociocultural sustainability of agricultural commodity production. Glob Environ Chang 42:33-46 
Rickels W, Dovern J, Hoffmann J, Quaas MF, Schmidt JO, Visbeck M (2016) Indicators for monitoring sustainable development goals: an application to oceanic development in the European Union. Earths Future 4:252-267

Rivers A, Barbercheck M, Govaerts B, Verhulst N (2016) Conservation agriculture affects arthropod community composition in a rainfed maize-wheat system in central Mexico. Appl Soil Ecol 100:81-90

Robertson GP, Dale VH, Doering OC, Hamburg SP, Melillo JM, Wander MM, Parton WJ, Adler PR, Barney JN, Cruse RM, Duke CS, Fearnside PM, Follett RF, Gibbs HK, Goldemberg J, Mladenoff DJ, Ojima D, Palmer MW, Sharpley A, Wallace L, Weathers KC, Wiens JA, Wilhelm WW (2008) Sustainable biofuels redux. Science 322(5898):49-50

RSB (2016) RSB-STD-01-002 (Version 1.0) RSB glossary of terms. Roundtable on sustainable biomaterials. https://rsb. org/wp-content/uploads/2018/07/RSB-STD-01-002-RSBGlossary-of-Terms-v.1.1.pdf. Accessed 24 May 2019

Seuring S, Muller M (2008) From a literature review to a conceptual framework for sustainable supply chain management. J Domest Prod 16:1699-1710

Smith A, Snapp S, Chikowo R, Thorne P, Bekunda M, Glover J (2017) Measuring sustainable intensification in smallholder agroecosystems: a review. Glob Food Secur 12:127-138

Sydorovych O, Wossink A (2008) The meaning of agricultural sustainability: evidence from a conjoint choice survey. Agric Syst 98:10-20

Tarr NM, Rubino MJ, Costanza JK, McKerrow AJ, Collazo JA, Abt RC (2017) Projected gains and losses of wildlife habitat from bioenergy-induced landscape change. Glob Chang Biol Bioenergy 9(5):909-923

Tarter A, Kennedy Freeman K, Sander K (2016) A history of landscape-level land management efforts in haiti- lessons learned from case studies spanning eight decades. World Bank Group-Agriculture. Washington, DC, September 2016

Tredick CA, Lewison RL, Deutschman DH, Hunt TA, Gordon KL, Von Hendy P (2017) A rubric to evaluate citizenscience programs for long-term ecological monitoring. BioScience 67:834-844

Tufte E (1983) The visual display of quantitative information. Graphics, Cheshire. ISBN 0-9613921-4-2
Varner J (2014) Scientific outreach: toward effective public engagement with biological science. BioScience 64:333-340

Verhulst N, Kienle F, Sayre KD, Deckers J, Raes D, LimonOrtega A, Tijerina-Chavez L, Govaerts B (2011) Soil quality as affected by tillage-residue management in a wheat-maize irrigated bed planting system. Plant Soil 340(1):453-466

Villa F, Bagstad KJ, Voigt B, Johnson GW, Portela R, Honzák M, Batker D (2014) A methodology for adaptable and robust ecosystem services assessment. PLoS ONE 9(3):e91001

Vörösmarty CJ, Rodríguez Osuna V, Koehler DA, Klop P, Spengler JD, Buonocore JJ, Cak AD, Tessler ZD, Corsi F, Green PA, Sánchez R (2018) Scientifically assess impacts of sustainable investments Metrics can inform investors wary of "green washing". Science 359(6375):523-525

Wheaton E, Kulshreshtha S (2017) Environmental sustainability of agriculture stressed by changing extremes of drought and excess moisture: a conceptual review. Sustainability. https://doi.org/10.3390/su9060970

Wiens J (2013) Is landscape sustainability a useful concept in a changing world? Landscape Ecol 28:1047-1052

Williams BK, Brown ED (2012) Adaptive management: the U.S. Department of the Interior Applications Guide. Adaptive Management Working Group, U.S. Department of the Interior, Washington, DC. ISBN: 978-0-615-599137. https://www2.usgs.gov/sdc/doc/DOI-Adaptive-Manage ment-Applications-Guide-27.pdf. Accessed 24 May 2019

Wu J (2013) Landscape sustainability science: ecosystem services and human well-being in changing landscapes. Landscape Ecol 28:999-1023

Yokessa M, Marette S (2019) A review of eco-labels and their economic impact. Int Rev Environ Resour Econ 13:119-163

Youngs H, Somerville C (2014) Best practices for biofuels. Science 344:1095-1096

Zenner EK (2016) Desirable and undesirable conditions as guides in natural resources management. $\mathrm{J}$ For 114(6):666-667

Publisher's Note Springer Nature remains neutral with regard to jurisdictional claims in published maps and institutional affiliations. 